\title{
feAture Managing Pymatuning swampland in northwestern Pennsylvania: A personal story
}

\author{
Kenneth R. Olson and Lois Wright Morton
}

$\mathrm{P}$

ymatuning Swamp lies buried beneath Pymatuning Reservoir, subdued but not forgotten, its legacy still visible in the hydric soils and wetlands of the reservoir backwaters (figure 1).This is a story of a changing climate, melting glaciers, ancient lakes filled with sediments, swamplands of northwestern Pennsylvania, and humanity's unceasing efforts to mold and manage the natural landscape for human uses. The footprint of the Adena culture, hunters and gatherers who grew corn (Zea mays L.), beans, and squash 3,000 to 1,000 years ago near the wetlands, was light. Their settlements thrived for a short period along Pymatuning Creek, the Shenango River, and Conneaut Lake swamp. By the late 1700s, Europeans attempted to settle the wet, forested region incentivized by the Pennsylvania Land Act. The human solution to this wetland wilderness of abundant white pine (Pinus strobus), beaver (Castor canadensis), and wildlife that was nearly impenetrable to travel was to construct the Beaver to Erie Canal in the 1830s. This extension of the Erie Canal connected the Ohio River via Beaver River north to Shenango River, over the continental divide to Lake Erie and quickened the transport and exchange of the wilderness's raw materials and East Coast's dry goods.

The Pymatuning swampland was flooded when the Pymatuning Dam was built in the 1930s to regulate and store floodwaters, one of the early public works efforts to manage river flooding. Uplands adjacent to the dam were used for both wildlife and agriculture. By the late 1950s, the Pennsylvania Game Commission, using the threat of eminent domain, acquired more than 4,000 ha $(10,000 \mathrm{ac})$ of farmland adjacent to the Pymatuning Reservoir to

Kenneth R. Olson is professor emeritus of soil science in the College of Agricultural, Consumer, and Environmental Sciences, University of Illinois, Urbana, Illinois. Lois Wright Morton is professor emeritus of sociology, College of Agriculture and Life Sciences, lowa State University, Ames lowa.

\section{Figure 1}

This wetland lake was formed when the canal towpath and road causeway was built into Pymatuning Swamp in the 1830 s to enable settlers and trappers to travel throughout the swampland.

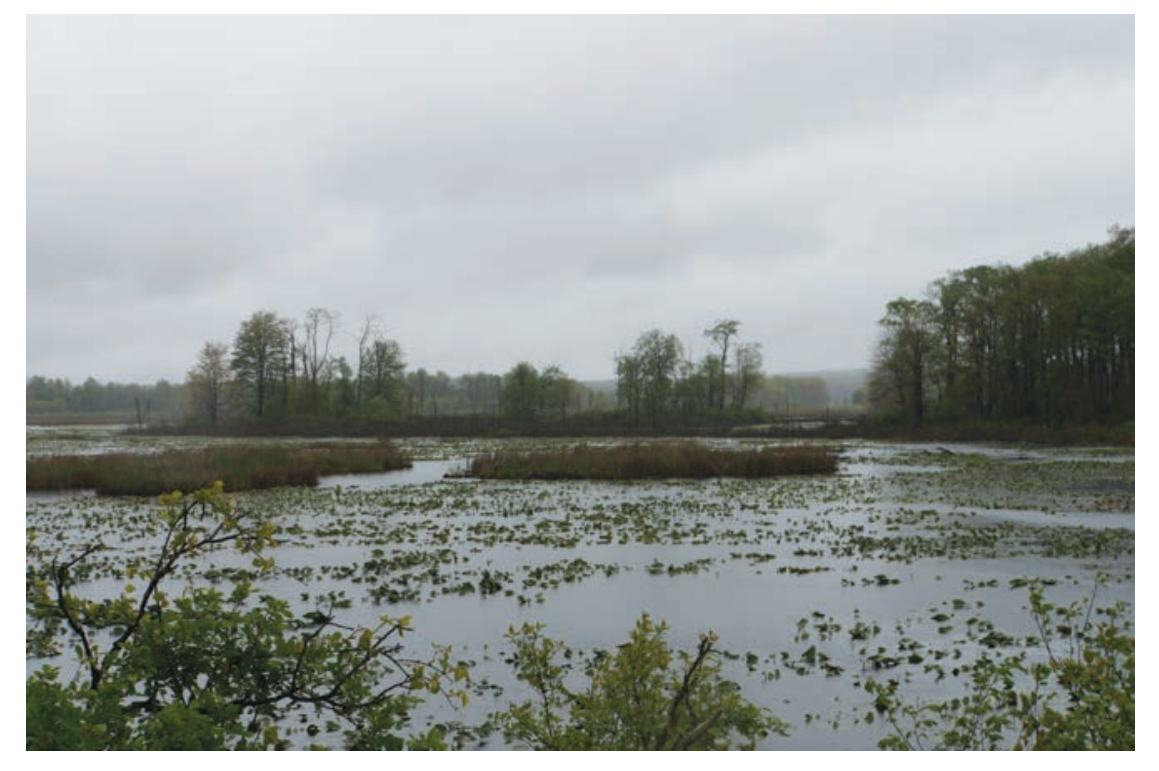

expand the Goose Management Area and displaced about 60 farm families. In most Midwest states, such as Illinois and Missouri, the Federal Swamp Acts of 1849, 1850, and 1860 were used to drain swamplands, cut timber, and convert the swamps to agricultural land (Olson et al. 2016a, 2016b). The Commonwealth of Pennsylvania did just the opposite: they took productive agricultural lands for wildlife, including the creation of a Goose Management Area on one of the major Canadian geese (Branta canadensis) flyways.

\section{CLIMATE CHANGE, GEOLOGY, AND SOILS OF CRAWFORD COUNTY, PENNSYLVANIA}

Conneaut Lake, Pymatuning swamplands, and the land surfaces of Crawford County, Pennsylvania, were greatly altered by two glaciers (figure 2), which advanced from the north during the Ice Age. The Illinoian glacier covered all of Crawford County, and the later Wisconsian glacier covered all but the southeastern corner of the county. These glaciers leveled ridges and hilltops, gouged valleys parallel to the ice as it pushed south, and then receded leaving a thick deposit of glacial drift in valleys and a thin mantle of soils on the uplands. The Valois, Cambridge, Venango, Frenchtown, and Alden soils formed in surficial Wisconsin till (Yaworski et al. 1979). After the Wisconsin glacier melted, about 15,000 years ago, the Crawford County land surface that had been depressed by great loads of ice began to rebound and rise. Cycles of upland and valley erosion were renewed, as shown by the high positions of the outwash terraces and two levels of postglacial alluvial deposits on flood plains. Haven and Scio soils formed in deposits on the older floodplains or high bottoms, and Pope, Philo, and Holly soils developed in the low bottoms with recent alluvium (Yaworski et al. 1979).

The soils of Crawford County formed from glaciation on bedrock and resulted in deposits of till, outwash, and lacustrine material from glacial drift (Sheppes et al. 1959). Major bedrock formations occur in three bands that cross the county diagonally in a southwest to northeast direction. The rock strata dip about 5 to $8 \mathrm{~m} \mathrm{~km}^{-1}$ $\left(15\right.$ to $\left.25 \mathrm{ft} \mathrm{mi}^{-1}\right)$. In the northwestern 


\section{Figure 2}

Parent materials deposited and soils located in Ashtabula County (Ohio) and Crawford and Erie counties (Pennsylvania) include the lacustrine deposits, the beach ridge, the glacial till and the southern limit of ice advance into the residual parent material areas.

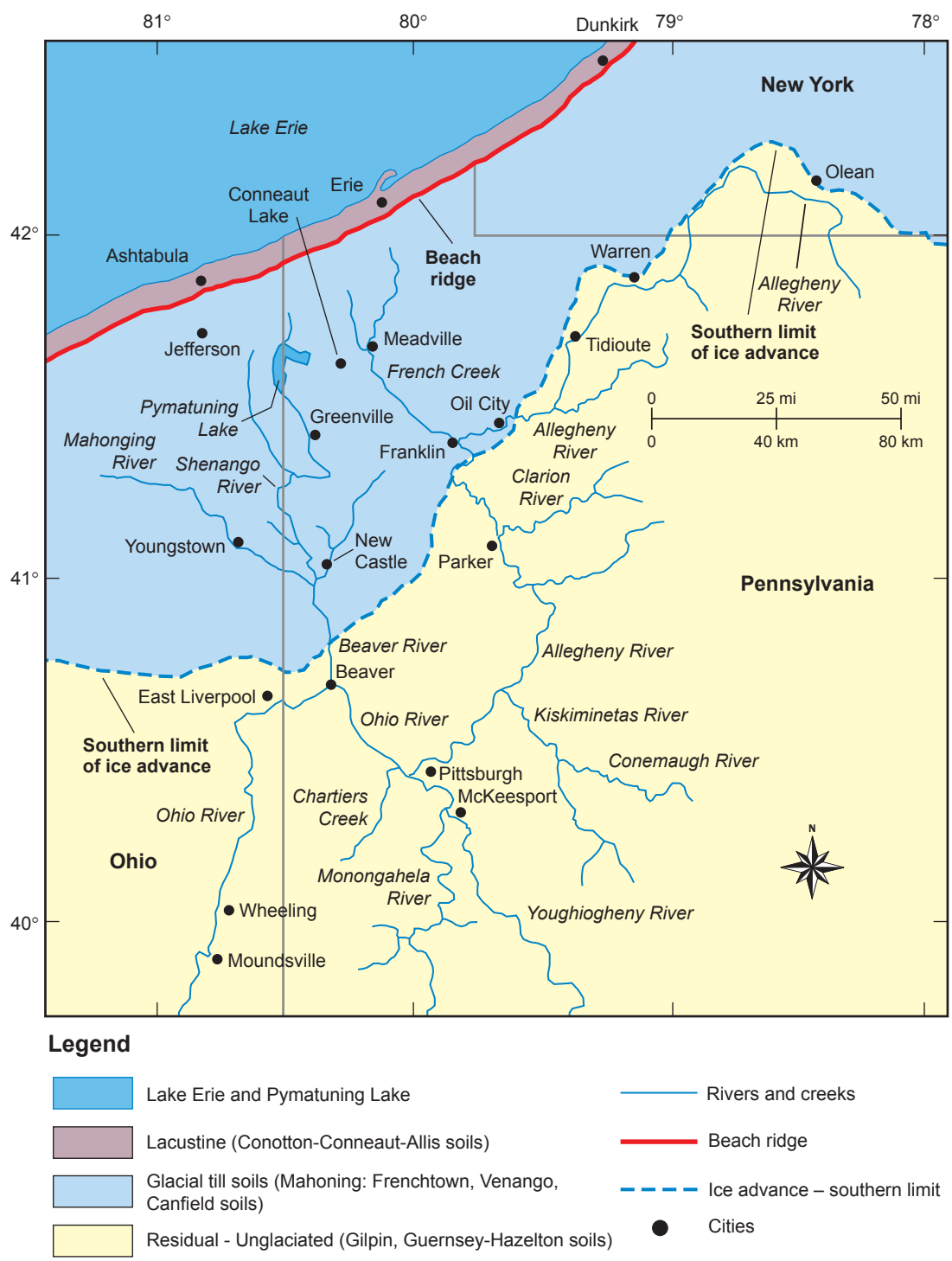

part of the county (Conneaut Lake and Pymatuning swampland area), the oldest bedrock exposed is shale, siltstone, and sandstone of the Cattararius and Riceville formations which are of Devonian age (Yaworski et al. 1979). Also in the geologic groups is the sandstone of the Venango Formation that contains oil.

Glacial outwash in Crawford County contains strata or lenses of sorted silt, sand, and gravel deposited by flowing glaciers. These glaciofluvial deposits are in scoured valleys, on terrace remnants of valley walls, tles, lakes, bogs, and swamps. Carlisle soils are formed in these organic deposits.

Today the climate of Crawford County is continental and humid. Similar to the past, the climate is continuing to change, and northeastern Ohio and northwestern Pennsylvania temperatures have increased by more than $0.8^{\circ} \mathrm{C}\left(1.5^{\circ} \mathrm{F}\right)$ when 1991 to 2012 averages are compared to 1901 to 1960 averages (Melillo et al. 2014). Further, this region has experienced a $71 \%$ increase in the amount of precipitation falling in very heavy events from 1958 to 2012 and a 10 day observed increase in frost-free season length during 1991 to 2012 relative to 1901 to 1960 (Melillo et al. 2014). Warm air masses that originate in the Gulf of Mexico, mild dry air masses that originate in western United States, and cold, dry air masses that come in from Canada influence the weather and climate. Late in fall and in winter before the Great Lakes freeze over, air masses over the lakes pick up moisture making winters cold and snowy.

\section{EARLY HUMAN USES OF PYMATUNING AND CONNEAUT LAKE SWAMP AREAS}

Legend places the Adena culture mound builders (500 to 1000 AD) as living near Conneaut Lake and Pymatuning swamplands. Little is known about these people, and it is not clear whether they are related to the Delaware Native Americans (Lenni Lenape) living in this region when European settlers arrived. Lenape communities, originally located along the Hudson and Delaware rivers, were weakened by European diseases (e.g., smallpox, cholera, influenza, and dysentery). The Lenape were driven west into the upper Ohio River Valley Basin in the 1700s by the Seneca tribe, a member of the Iroquois Confederacy. The Lenape (also called the Erie Tribe) were ruled by a queen noted for her cunning strategy and crooked dealings. The Iroquois name, "Pymatuning" means, "The Crooked-Mouthed Man's Dwelling Place" with "crooked-mouthed" translated as deceitful (Sturtevant and Trigger 1978).

A 1785 treaty between the Iroquois Confederation and Wyandot Nation deeded the area north of the Ohio River to the Commonwealth of Pennsylvania, opening the way for settlers from New 


\section{Figure 3}

The Pymatuning Dam on the Shenango River transformed Ohio and Pennsylvania swampland into a storage lake to regulate the release of water and a recreational area for hunters, fishers, and boaters. South of the Lake Erie-Ohio River drainage divide are the Pennsylvania Game Commission lands and the former Olson farm.

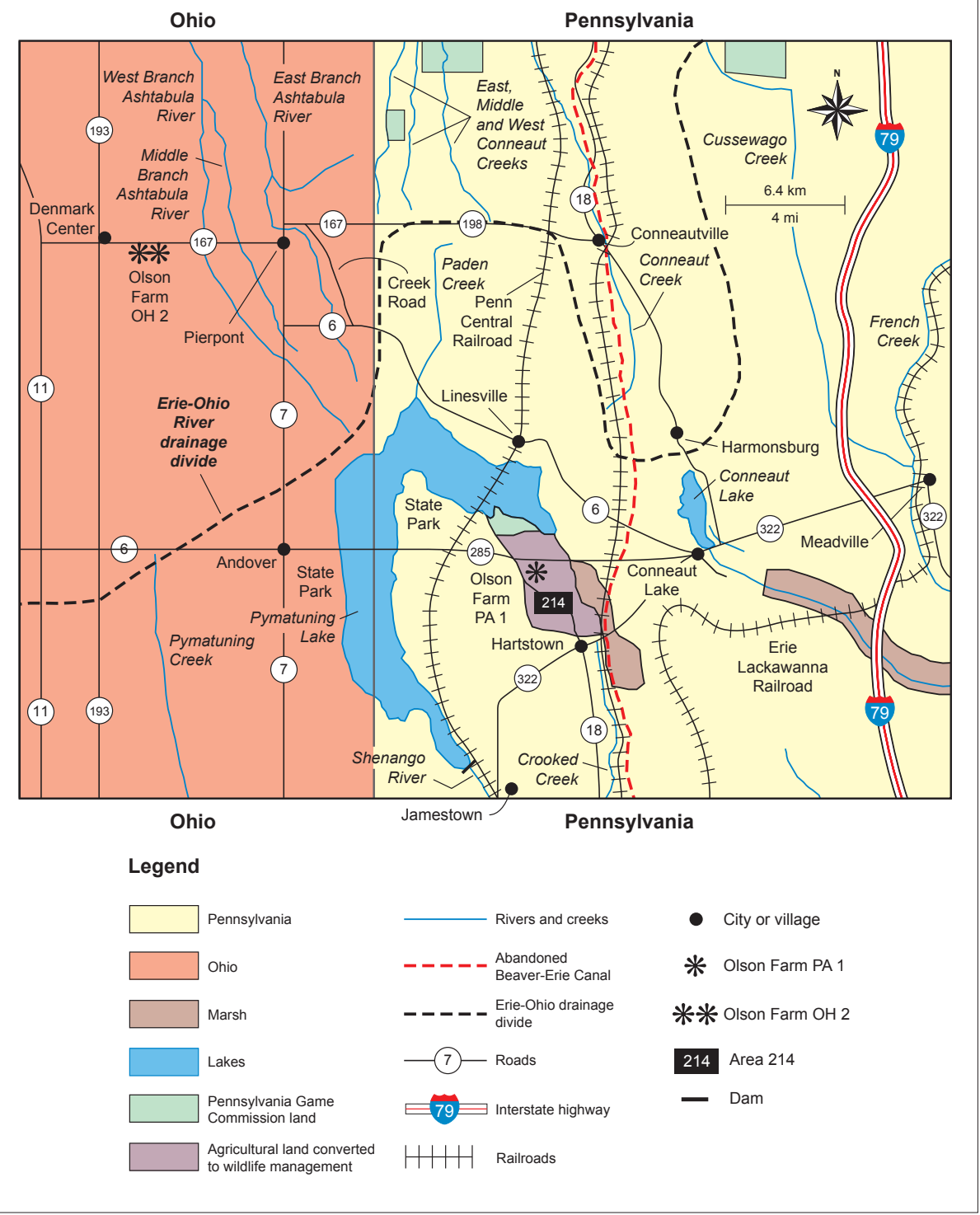

York and Connecticut to safely travel west and settle in new lands (Sturtevant and Trigger 1978). The first European settlers in French Creek valley of northwestern Pennsylvania arrived in 1788 and founded the town of Meadville (figure 2) in 1794. The Conneaut Lake swampland about $10 \mathrm{~km}$ (6 mi) west of Meadville and the Pymatuning swampland $32 \mathrm{~km}$ (20 mi) west of Meadville extended into the territory west of Pennsylvania, which in 1803 became the state of Ohio. Meadville quickly grew as a commerce and transportation hub with local lumber, especially white pine, shipped to Pittsburgh markets via French Creek and the Allegheny River; Pittsburgh dry goods and supplies were shipped north on return trips. Settlement by white immigrants into the Pymatuning and Conneaut Lake swampland areas in the Ohio territory and western Pennsylvania was slow prior to 1803. Travel through the impenetrable forested Pymatuning and Conneaut swamps was extraordinarily difficult with trappers and hunters the most successful at making a living from the wetlands. However, travel was soon improved with the construc- tion of the Beaver and Erie Canal in 1831, six years after the completion of the Erie Canal through New York State.

\section{TRANSPORTING LUMBER, BEAVER PELTS, AND PEOPLE: THE BEAVER AND ERIE CANAL}

There were three sections to the Beaver and Erie Canal: the Conneaut Division, the Shenango Division, and the Beaver Division. This canal, also called the Erie Canal Extension, flowed 219 km (136 mi) from the Ohio-Beaver rivers' confluence (figure 4) north to the city of Erie located on Lake Erie. It required 137 locks to overcome the elevation change of $298 \mathrm{~m}$ (977 ft) between the Ohio River and Lake Erie. This network of rivers and canals was intended to connect Lake Erie (Great Lakes basin) to the Ohio River (Mississippi River basin), to the Main Line of Public Works (a canal between Pittsburgh and Philadelphia), and to the New York State Erie Canal. The New York State Erie Canal linked Great Lake ports Buffalo and Oswego to rivers flowing east through the Finger Lakes and Mohawk River to Albany, New York; the Hudson River; and, finally, the Atlantic Ocean.

In 1831, the Beaver Division was begun. It ran $50 \mathrm{~km}(31 \mathrm{mi})$ from the town of Beaver along the Beaver and Shenango rivers to Pulaski. Five years later, digging for the $98 \mathrm{~km}$ (61 mi) Shenango Division was begun, followed in 1838 by contracts for the construction of the Conneaut Division extending $72 \mathrm{~km}$ (45 mi) north to Erie. These three divisions of the Beaver and Erie Canal were opened to traffic in 1844. The canal (figure 5) passed along a $4.8 \mathrm{~km}$ (3 mi) causeway constructed through Pymatuning Swamp and formed the current US Route 322 near Hartstown and a $2.4 \mathrm{~km}^{2}$ (600 ac) Pymatuning Reservoir west of the canal.

Two east-west canals linked boat traffic to the Beaver and Erie Canal. At New Castle, the Pennsylvania and Ohio Canal (figure 2) intersected with the Beaver and Erie Canal and ran $146 \mathrm{~km}$ (91 mi) west to the Ohio and Erie Canal. Another east-west canal was the French Creek Feeder that brought water into Conneaut Lake. Because Conneaut Lake, a kettle lake (figure 3), was fed primarily by springs and small streams, it needed the feeder canal to ensure sufficient 
water to fill the Beaver and Erie Canal for navigation. The feeder canal flowed from a dam constructed on the Bemus farm, $3 \mathrm{~km}$ (2 mi) southeast of Meadville, to the Erie and Beaver Canal and the Beaver River (figure 2). The impounded water was at a higher elevation than Conneaut Lake, and the feeder flowed northwest to Meadville. Engineering projects included adding another short canal to carry water, a pumping station for the Beaver and Erie Canal, and the raising of the Conneaut Lake dam by $2.7 \mathrm{~m}$ (9 ft). The feeder canal crossed French Creek via an aqueduct at Shaw's Landing where a lock system enabled canal boats to transfer between French Creek and the Beaver and Erie Canal.

The Beaver and Erie Canal was heavily used when it was first built, and it brought new business to towns that shipped timber and hay to Pittsburgh. However, the collapse of an aqueduct over Elk Creek in Erie County, Pennsylvania, in 1872 (figure 5 ) and competition from railroads made the canal unprofitable and led to it being abandoned (Helmreich 2005). Sections of the main canal and feeders were used for local traffic a short while until usage dropped and maintenance and repair costs became unsustainable. In some places the old canal towpath is currently used for hiking trails and many of the communities along the canal display related artifacts in their historical museums.

\footnotetext{
REGULATING AND STORING FLOOD WATERS: PYMATUNING DAM AND LAKE "All human accomplishments begin with a dream." These lofty words were spoken by Governor Gifford Pinchot of the Commonwealth of Pennsylvania in 1934 at the dedication of the Pymatuning Dam on the Shenango River (figure 6). The dream began in the nineteenth century when in 1868, the General Assembly authorized a survey and preparation of a cost estimate to reclaim the Pymatuning swamplands by flooding. This highly unusual approach to wetland reclamation contrasted with the extensive drainage of swampland across the US Midwest during this period, incentivized by the US Swampland Acts of 1850 to 1860 to make new agricultural lands (Olson and Morton 2016).
}

\section{Figure 4}

The Beaver River (right) flows under this railroad bridge to its confluence with the Ohio River (left). Beaver was the southern terminus of the Beaver and Erie Canal connecting Lake Erie to the most northern point of the Ohio River about $32 \mathrm{~km}$ (20 mi) downstream from Pittsburgh, Pennsylvania (see figure 2).

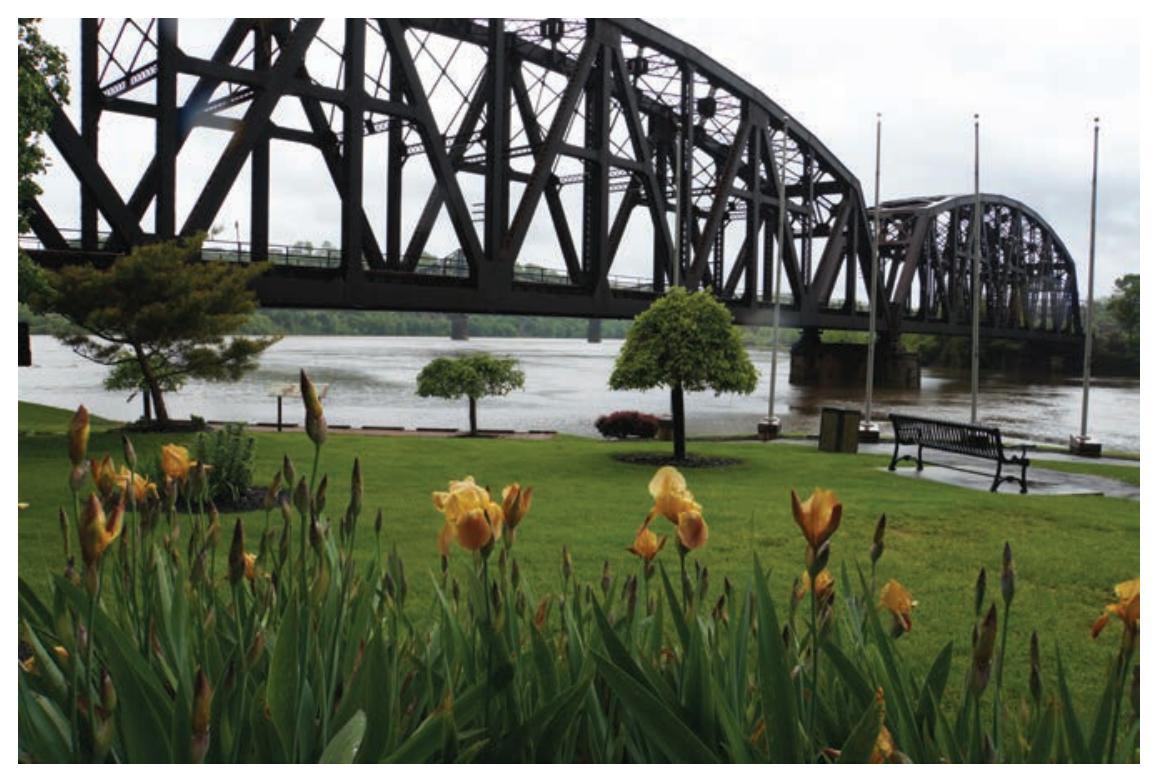

\section{Figure 5}

The Beaver and Erie Canal was unable to compete with the growing network of railroads that transported raw materials, dry goods, and people much more quickly. Here a railroad is built on the abandoned canal towpath.

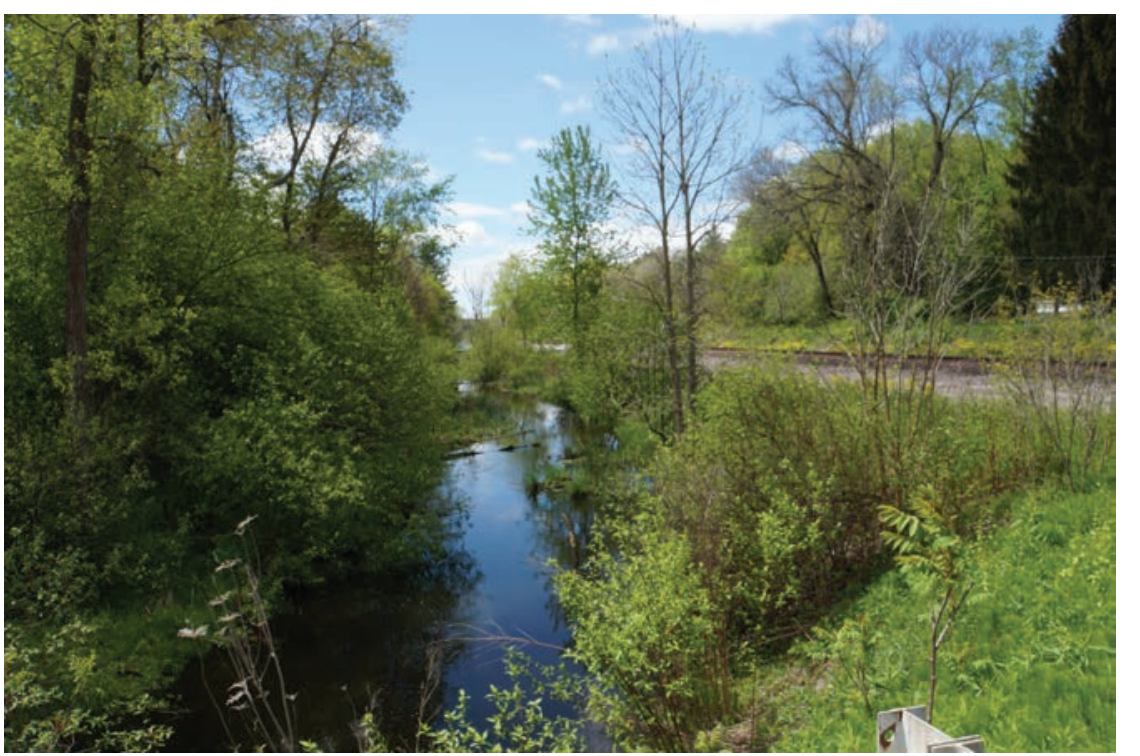

It was not until after the disastrous Flood of 1913 pushed the Ohio River to record flood crests (Olson and Morton 2016); destroyed homes, businesses, and bridges; and took lives on headwater tributaries (the Shenango and Beaver rivers in Pennsylvania) that dollars were appropriated and construction begun. The passage of The Pymatuning Act by the Pennsylvania legislature to dam the Shenango River and build a reservoir for water storage to regulate the flow in the 
Shenango and Beaver rivers was one of the first of projects of its kind (Engineering and Contracting 1914). Pennsylvania was ahead of its time in recognizing the value of water storage reservoirs to manage downstream river flooding. When the Flood of 1937 wreaked havoc across the entire Ohio Valley, the US government finally passed the 1938 Flood Control Act that led to hundreds of upstream dams and reservoirs to store and regulate river flows and manage flooding (Olson and Morton 2016). Today, these upstream dams and reservoirs are essential structures for ensuring sufficient water for navigation and to manage flooding on the Ohio and Mississippi rivers and their tributaries.

The reservoir flooded almost 1,214 ha $(3,000 \mathrm{ac})$ of swamp and 3,392 ha $(8,383 \mathrm{ac})$ of dry, tillable land; submerged 53 homes and 56 barns; and required the relocation of $17.7 \mathrm{~km}$ (11 $\mathrm{mi}$ ) of highway and elevation of $2.7 \mathrm{~km}(1.7 \mathrm{mi})$ of railroad (Engineering and Contracting 1914).

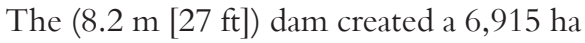
$(17,088 \mathrm{ac})$ reservoir $27 \mathrm{~km}$ (17 mi) long, $2.6 \mathrm{~km}(1.6 \mathrm{mi})$ at is widest point with an average depth of $4.6 \mathrm{~m}(15 \mathrm{ft})$ and deepest

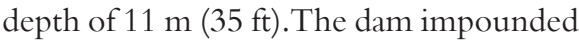
$2.43 \times 10^{8} \mathrm{~m}^{3}\left(6.43 \times 10^{10} \mathrm{gal}\right)$ of water at $305 \mathrm{~m}(1,000 \mathrm{ft})$ above sea level. A $3.2 \mathrm{~km}$ ( $2 \mathrm{mi}$ ) causeway and bridge between the states of Ohio and Pennsylvania across the middle of the reservoir enable free flow of water between the two basins as well as passage of sailboats and other watercraft.

The upstream portion of the reservoir that curves east, where a railroad and road cross the lake (see figure 3), has a bell-mouth spillway used to control the flow of wetland water into the lake. The spillway can hold back water during the dry season for wetland wildlife, or during rainy seasons, release water to drain over the spillway and under the road into the main body of Pymatuning Lake. This is the Linesville Spillway, also known as, "where the ducks walk on the fish," and where tourists have been throwing food (old bread) for the last 70 years at the fish, primarily very large carp. About 300,000 to 500,000 tourists annually come to the spillway to throw food at the fish, ducks, and Canadian geese. A migratory flyover, the Pennsylvania Game Commission

\section{Figure 6}

The gate house on the Pymatuning Dam (732 m across and $15 \mathrm{~m}$ high) near Jamestown, Pennsylvania, was repaired in 2016 to 2017. The gate structure allows water to flow through the dam via a $0.6 \mathrm{~m}$ diversion channel where it travels $85 \mathrm{~m}$ to outflow conduits.

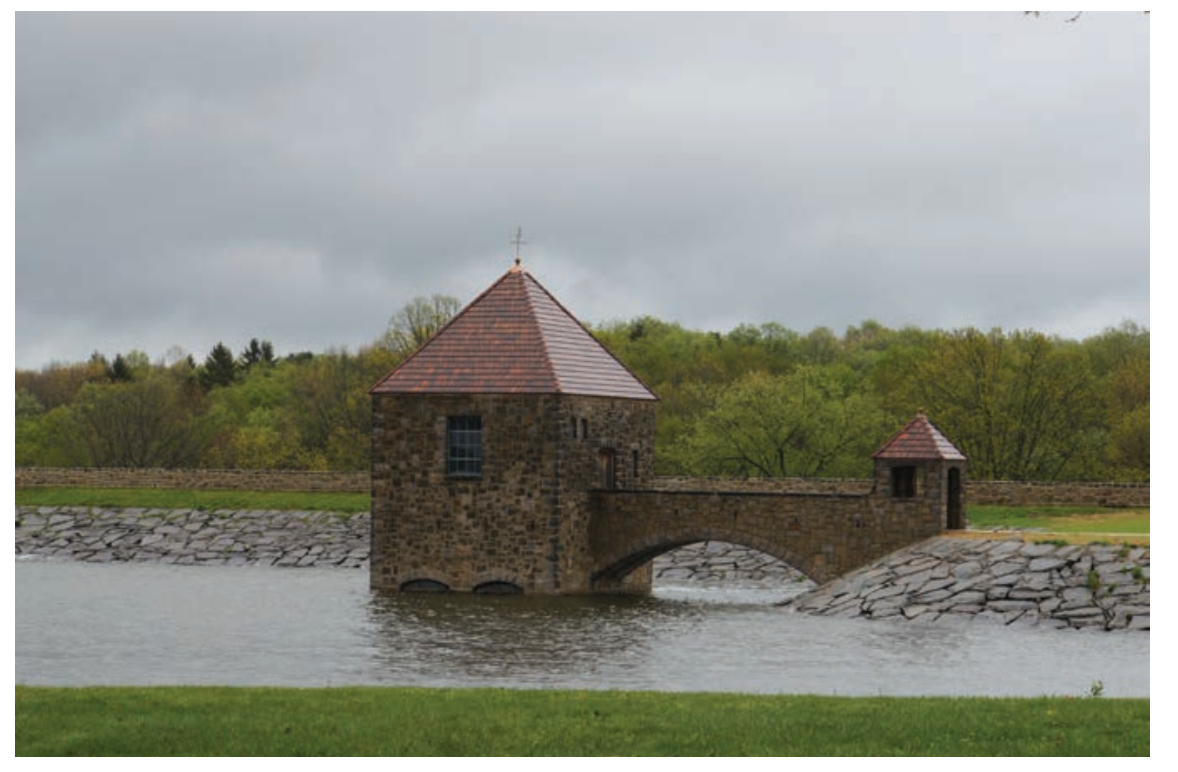

has been highly successful in establishing Canadian geese breeding colonies in protected wetlands and cultivated uplands around the lake. Hand feeding by tourists has made the aggressive and territorial geese fearless of humans as they beg for food, with the unintended consequence of creating a nuisance bird in the region.

\section{LAND USE CHANGE: A PERSONAL STORY}

Construction of dams and reservoirs create dramatic change on the landscape and in the lives people who live there. First author of this paper, Ken Olson, having twice experienced firsthand the loss of his family farm due to land use changes associated with dam and reservoir building puts a human face on the impacts. Here is his story:

After the Olson family experienced the loss their North Dakota farm in the 1950s when farmland was flooded by the construction of the Garrison Dam and Lake Sakakawea (Olson and Morton 2017), our family (my parents, sister, and me) moved to Pennsylvania. This time the farm my parents purchased was adjacent to Pymatuning Reservoir but on the upland with little chance of losing the farm to flooding again. However, only four years after we started our new dairy farm, the Commonwealth of
Pennsylvania decided to use the threat of eminent domain to acquire farms for a Pennsylvania Game Commission Goose Management Area. Apparently my parents had made another mistake. They bought farmland that was too close to Pennsylvania Game Commission Land, Pymatuning Lake, and the Pymatuning and Conneaut swampland, a major Canadian geese flyway (figure 3). The state of Pennsylvania purchased 4,400 ha (11,000 ac) of land, mostly dairy and grain farms, to create the Goose Management Area, where at least one third of the grain crops had to be left in the fields to feed the Canadian geese by adjacent farmers who rented the land and grew the crops.

The intent of the Pennsylvania Game Commission was to use the Pymatuning Swamp as a breeding ground for the Canadian geese to increase their numbers by providing grain in fields (which eventually required the purchase of 60 private farms and 20 homeowner lots). They brought in Canadian geese, clipped their wings to prevent them from flying away, and raised them in large pens adjacent to the Pymatuning Reservoir on existing Pennsylvania Game Commission lands. In the fall the sky was full of thousands of Canadian geese flying above the Pymatuning Reservoir, Pymatuning swampland, Conneaut Lake swampland, Game Commission land, and adjacent farmland 
including my family's dairy farm, which became one of the targeted farms for acquisition.

My parents had purchased a 73 ha (180 ac) dairy farm in 1954 about 2 or $3 \mathrm{~km}$ (1 or 2 mi) south of the Pymatuning and Conneaut Lake swamplands. While I was in grade school we began to hear rumors that the Pennsylvania Game Commission was interested in purchasing farmland in Area 214 for a Goose Management Area (figure 3). The farmers, landowners, and even homeowners did not believe the Game Commission would take their land. Most of the farms were dairies with significant investment in farmsteads, barns, and other buildings. However, my family and other landowners began to receive notices from the State of Pennsylvania asking them to sell their land. The largest block of farmland, over 4,000 ha (10,000 ac) surrounded our farm (Olson Farm PA1, figure 3). Dad and Mom organized a meeting of the affected area landowners, including some of the farmers located outside of Area 214. The soils on the Olson farm were Venango and Frenchtown (Yaworki et al. 1979), well suited for cultivated crops and high quality grasses for milk cows. One by one, all the farmers, except my parents, sold their farms under the threat of eminent domain. The state of Pennsylvania was required by law to pay landowners the fair market value, which was determined to be US\$250 ha $\mathrm{h}^{-1}$ (US\$100 $\left.a c^{-1}\right)$, including all farm buildings and farmsteads that were going to be torn down. One of the first to sell was the owner of a small dairy farm who shared a hay baler with Dad. He took the \$6,900 for his 28 ha (69 ac) dairy farm and moved back to West Virginia.

My family was the last to sell. They had the largest dairy with farm buildings and a farmstead and received US\$800 ha ${ }^{-1}$ (US\$280 ac ${ }^{-1}$ ) for 72 ha (180 ac). Apparently, the Game Commission did not want to actually use its eminent domain powers and contest the land ownership issue in court (or did not need to), and the farmers did not have money for a court suit. Had a case been brought to court, the area farmers would have likely lost. All the targeted farmland was acquired, and plans were made to construct a Goose Management Area by removing woodlots, farmsteads, and buildings to permit farming all the land on the contour with strip cropping. Ponds were built, and most of the original agricultural land stayed in grain production. The land was then leased to area farmers living adjacent to but outside Area 214 (figure 3), and they were required to leave about one-third of the crop in the field for the geese. Almost all the homes, barns, and buildings were removed by 1960 from the more than 80 tracts of land with just a few exceptions. Our new barn addition was new enough to be kept for 30 years as a storage shed for Game Commission purposes and was then removed.

Dad, Mom, my sister, and I moved $48 \mathrm{~km}$ (30 mi) to the west across Pymatuning Lake into Ashtabula County, Ohio, and purchased another dairy farm (Olson Farm OH-2, figure 3) with the hope that the state of Ohio or the federal government would not come for our farm a third time. The move impacted our family, especially my sister (12 years old) and me (14 years old) as a result of leaving friends and going to a new school, new church, and new state for the second time in six years. After 60 years, I still find it amazing that the Commonwealth of Pennsylvania could take 60 active farms (food security had not yet become an issue) on 80 tracts with over 4,000 ha (10,000 ac) of private agricultural and forest lands and turn the land into a Goose Management Area.

This land use conversion was just the opposite of what happened in southern Illinois swampland and Missouri Big Swamp where, after the Swamp Acts of 1849, 1850 and 1860, Midwest states converted their swamps to agricultural use by draining the swamps: 180,000 ha $(450,000$ ac) in southern Illinois's Cache River Valley (Olson and Morton 2014) and 400,000 ha $\left(1 \times 10^{6} \mathrm{ac}\right)$ in Missouri's Big Swamp (Olson et al. 2016a, 2016b). The timber in these swamps was removed, stumps pulled, and crops planted. Pennsylvania flooded most of the Pymatuning Swamp in the 1930s after they built the Pymatuning Dam and made much of the remaining wetlands and adjacent uplands a wildlife and game preserve.

\section{TRADE-OFFS OF MANAGING FOR COMMERCE, AGRICULTURE, THE ENVIRONMENT, AND FLOOD CONTROL}

As the Pymatuning and Conneaut Lake swamp areas were settled, the Beaver and Erie Canal and feeder lines were built to transport lumber, pelts, finished goods, and people throughout the region and to East Coast markets from 1844 to 1872. However, the canal's usefulness was shortlived; railroads put the Beaver and Erie Canal out-of-business by the end of the 1800 s. With the growth of commerce and settlements along the Shenango and Beaver rivers, a new threat emerged: river flooding. As a result, flood management became a major concern, and the Shenango River was dammed for water storage and to regulate the flow of the river downstream. The resulting reservoir and adjacent wetlands became a prime area for wildlife and recreational hunting and fishing rather than agricultural productivity. The people of Pennsylvania and their public decision makers appear to have historically valued its wildlife and wetland ecosystems more than other states who reclaimed swamps to expand their agricultural lands.

There seem to be few records about the fate of the the families whose lands were flooded in 1930s by the Pymatuning Dam and Reservoir and the other 59 farm families whose land the Game Commission purchased in the late 1950s. As we have studied the impact of Ohio and Mississippi river and tributary flooding on agricultural lands (Morton and Olson 2014), we have seen how natural flooding resulted in thousands of people living in the floodplains losing homes, businesses, and sometimes lives. When the US Army Corps of Engineers or state governments attempt to manage great rivers and tributaries, it has resulted in thousands of families required to move out of river valleys. These changes in land uses have affected US families for almost three centuries, and a growing population suggests managing rivers in the context of human uses will only continue to become more complex and create difficult trade-offs: the locks and dams from the 1830 s to present (Morton and Olson 2019); the Little River Drainage District diversion south of Cape Girardeau in the 1910s (Olson et al. 2016a, 2016b); the Birds Point-New Madrid Floodway in the 1920s and 1930s; the Afchafalaya Floodway in the 1930s; the Bonnet Carre Spillway and Floodway in the 1930s; the Morganza Floodway in the 1930s; the Kentucky Dam on the Tennessee River in the the 1940s; the Barkley Reservoir on the Cumberland River in the 1960s; the Land Between the Lakes acquisition in the 1960s; and the hundreds of other reservoirs and water storage areas built to control flooding on the Ohio and Mississippi rivers and their 
tributaries (Olson and Morton 2016). The effect on families numbers in the hundreds of thousands with some moved by nature (e.g., the 1913, 1927, 1937 and 2011 floods) and others, postdisaster, by human engineering and management solutions. These solutions include construction of levees, locks and dams, canals, and reservoirs proposed primarily to control flooding or maintain navigation (Camillo 2012; Olson and Morton 2016).

For the last 60 years, Olson has often traveled back to the site of the Olson Pennsylvania farm (figure 3) and reflected on the impact the loss of the family dairy farm to the Goose Management Area had on him and his family and pondered the consequences and impacts on the other affected farm families. As we have coauthored other articles on the impacts of flooding, we have also wondered what happened to all of those families in Ohio, Pennsylvania, Kentucky, Indiana, Illinois, Missouri, Arkansas, Tennessee, Mississippi, and Louisiana that have been affected by nature (flooding) or by federal and state attempts to manage river landscapes (Morton and Olson 2014). The tension among human values and uses of rivers and wetlands is a persistent pattern throughout US history. Many of these land use changing events occur as a result of federal and state attempts to manage great rivers and their tributaries to serve multifunctional purposes. Ultimately, there are difficult trade-offs to make among economic, ecological, and social impacts, and few decisions are a win for all.

\section{ACKNOWLEDGEMENTS}

Published with funding support from USDA National Institute of Food and Agriculture, Water Division; the Director of the Illinois Office of Research, College of Agricultural, Consumer, and Environmental Science, University of Illinois at Urbana, Illinois; and the Iowa Agriculture and Home Economics Experiment Station, College of Agriculture and Life Sciences at Iowa State University, Ames, Iowa.

\section{REFERENCES}

Camillo, C.A. 2012.Divine Providence:The 2011 Flood in the Mississippi River and Tributaries Project. Vicksburg, MS: Mississippi River Commission.

Engineering and Contracting. 1914. A \$1,600,000

Water Storage Project. Plans for regulating flow of Shenango and Beaver Rivers. November 4, Vol. XLII, No. 19:30-31. Archived by Historical Society of Western Pennsylvania, Pittsburgh, Pennsylvania.

Helmreich, J.E. 2005. The course of French creek's history. Meadville, Pennsylvania: Allegheny College, French Creek Watershed Research Program.

Melillo, J. M., T.C. Richmond, and G. W. Yohe, eds. 2014. Climate Change Impacts in the United States:The Third National Climate Assessment. US Global Change Research Program, doi:10.7930/ J0Z31WJ2. https://nca2014.globalchange.gov/.

Morton, L.W., and K. R. Olson, 2014. Addressing soil degradation and flood risk decision making in levee protected agricultural lands under increasingly variable climate conditions. Special issue on Environmental Degradation. Journal of Environmental Protection 5(12):1220-1234.

Morton, L.W., and K.R. Olson. 2019. Securing the nation's infrastructure: The Ohio River. Journal of Soil and Water Conservation 74(1):5A-11A, doi:10.2489/jswc.74.1.5A.

Olson, K.R., and L.W. Morton. 2014. The 2011 Ohio River flooding of the Cache RiverValley in southern Illinois. Journal of Soil and Water Conservation 69(1):5A-10A, doi:10.2489/jswc.69.1.5A.

Olson, K.R., and L.W. Morton. 2016. Managing Mississippi and Ohio River Landscapes. Ankeny, IA: Soil and Water Conservation Society.

Olson, K.R., and L.W. Morton. 2017. Managing the upper Missouri River for agriculture, irrigation, flood control, and energy. Journal of Soil and Water Conservation 72(5):105A-110A, doi:10.2489/jswc.72.5.105A.

Olson, K.R., L.W. Morton, and D. Speidel. 2016a. Little River Drainage District conversion of Big Swamp to fertile agricultural land. Journal of Soil and Water Conservation 71(2):37A-43A doi:10.2489/jswc.71.2.37A.

Olson, K.R., L.W. Morton, and D. Speidel. 2016b. Missouri Ozark Plateau Headwaters Diversion engineering feat. Journal of Soil and Water Conservation 71(1):13A-19A, doi:10.2489/ jswc.71.1.13A.

Sheppes, V.C., G.W. White, J.B. Droste, and B.F. Sitler. 1959. Glacial geology of northwestern Pennsylvania. Bulletin G-32. Harrisburg, PA Department of Internal Affairs, Topographic and Geologic Survey.

Sturtevant, W.C., and B.G. Trigger. 1978. Handbook of North American Indians, Vol. 15: Northeast. Washington, DC: Smithsonian Institution.

Yaworski, M., D. Rector, J. Eckenrode, E. Jensen, and R. Grubb. 1979. Soil Survey of Crawford County, Pennsylvania. Washington, DC: USDA Soil Conservation Service. 